\title{
Economic potential of site-specific pesticide application scenarios with direct injection and automatic application assistant in northern Germany
}

\author{
Sandra Rajmis ${ }^{1,2}$. Isabella Karpinski ${ }^{1}$ (D) . Jan-Philip Pohl ${ }^{3} \cdot$ Marco Herrmann $^{4}$. \\ Hella Kehlenbeck ${ }^{1}$
}

Accepted: 3 February 2022 / Published online: 2 March 2022

(C) The Author(s) 2022

\begin{abstract}
A growing and promising sector of precision agriculture is the site-specific application of pesticides, having a high potential for reductions in pesticide use. Within the research project 'AssSys', site-specific pesticide applications with a direct injection sprayer system and an automatic application assistant were evaluated economically with respect to herbicide and fungicide applications. The application assistant aims to support farmers in decision-making and implementation of site-specific pesticide applications either in the planning stage or as ex-post analysis. The economic assessment was based on field trials and scenario analysis referring to a model farm. The field trials were conducted in 2018 and 2019 in northern Germany. In the scenario analysis, two site-specific application scenarios were compared to conventional uniform treatment (100\% of the field area). Weed monitoring was conducted as (1) standard procedure according to integrated pest management, (2) camera-based and (3) drone-based in the field trials. The pesticide application costs include pesticide costs, labour and machine costs of monitoring and pesticide applications. Investment costs of the necessary technical equipment for site-specific applications were included as annual labour and machine costs. As a major key performance indicator of partial budgeting at field level, extended gross margins were calculated. The economic scenario analysis showed pesticide application cost savings from 26 to $66 \%$ for site-specific applications compared to conventional applications. The average extended gross margin for site-specific applications of $787 € \mathrm{ha}^{-1}$ compared to $631 € \mathrm{ha}^{-1}$ for conventional application showed a clear economic advantage of the site-specific application scenarios. Site-specific pesticide applications can support farmers in implementing precise, sustainable and economically beneficial pesticide management. The technology presented may contribute to meet the goals of the European Green Deal to reduce use and risks of pesticides.
\end{abstract}

Keywords Sustainable crop production $\cdot$ Site-specific pesticide applications · Assistance system $\cdot$ Economic assessment $\cdot$ Scenario analysis

Isabella Karpinski

Isabella.Karpinski@julius-kuehn.de

Extended author information available on the last page of the article 


\section{Introduction}

The sustainable use of pesticides is a core element of sustainable agriculture. At the European level, this has been addressed with the Directive 2009/128/EC of the European Parliament and of the Council of 21 October 2009 establishing a framework for Community action to achieve the sustainable use of pesticides. This directive also implies the establishment of national action plans. The German National Action Plan on sustainable use of plant protection products (NAP) aims at reducing the risks of pesticide use (Federal Ministry of Food \& Agriculture, 2013), thus fostering the implementation of integrated pest management (IPM) as well as technical innovations for reducing the risks of pesticide applications.

According to the principles of IPM, the use of pesticides must be limited to the smallest possible share and carried out according to the principle of 'as little as possible, as much as necessary'. For this purpose, many procedures and measures are applied, supported by modern plant protection technologies and increasingly methods supported by digitisation. In addition, social demands for a reduction in the use of pesticides are also reflected in the European Green Deal and require suitable processes and approaches.

Methods of precision agriculture, such as site-specific pesticide applications, support the goal of reducing pesticide applications. Compared to conventional uniform pesticide applications which are usually carried out at $100 \%$ of the field area, site-specific pesticide applications only target those areas of the field, where weeds, pests or pathogens appear at a density exceeding economic threshold levels. Several studies have found herbicide savings using site-specific application procedures. Lettner et al. (2001) observed reductions in herbicide use with site-specific applications by 30 to $70 \%$ compared to conventional treatment. Nordmeyer et al. (2003) and Hufnagel et al. (2004) reported reductions in herbicide use of 40 to 50\%, Timmermann et al. (2003) between 50 and $70 \%$ and Gerhards and Christensen (2003) between 60 and 90\% compared to areas treated 100\%. Concerns that reductions of application rates using site-specific management are leading to higher weed pressures and in consequence, to increased application rates in the following crop seasons, could not be confirmed (Nordmeyer et al., 2003).

Direct injection is a necessary spraying technique to implement site-specific applications. Field sprayers with direct injection are able to apply several pesticides in one pass being separately dosed independently of each other without delay and with pinpoint accuracy. In conventional applications with standard systems, only one pesticide is applicable per tractor pass with one dosage (due to one tank). Therefore, the likelihood of a farmer driving to the field several times to apply pesticides site-specifically is small under efficiency considerations. Up to now, tank mixtures have been used predominantly, making site-specific application of individual agents impossible. Some further advantages of direct injection are that there are no residual amounts of spray liquid due to the mixing of pesticides and water for application takes place shortly before the nozzle.

Automatic site-specific applications require application maps, which rely on exact global navigation satellite systems (GNSS) supported field measurement and monitoring results of the particular field to be treated from sensors or drones, which is currently implemented in agricultural practice only to a limited extent. While eight of ten German farmers are actually using a small share of precision agriculture technologies-mainly farm management systems and drones -investment costs of direct injection sprayers are still relatively high, and farmers are sceptical towards data security (Agra-Europe, 2020). However, the number of farmers and contractors applying these technologies is 
slowly increasing (Rasmussen et al., 2020). Further precision agriculture applications by German farmers are digital field measurement, soil sampling and yield mapping (Hinck et al., 2016). For digital field measurements, farmers take advantage of global navigation satellite systems installed on their tractor and an RTK station located nearby. After driving along the field boundaries, the field information from the tractor pass can be supplemented with accurate satellite data on the location, providing the basis for any application maps. Soil mapping is necessary for site-specific fertilisation management. Exact nutrient distribution and concentration in the field-and provision of this information as nutrient map-allow farmers to provide site-specific fertilisation. Yield mapping - also with GNSS data support-is used to estimate crop yield and moisture content.

Recently, the assistance system 'pesticide application manager' (PAM) has been developed which is able to automatically consider legal distance requirements to water bodies and landscape structures during pesticide applications via section control (Federle et al., 2014; Rajmis et al., 2016). The most recent developments in precision plant protection are site-specific applications with direct injection field sprayers (Pohl et al., 2017).

Site-specific herbicide applications have been described e.g. by Gerhards and Christensen (2003), Nordmeyer et al. (2003), Timmermann et al. (2003) and Hufnagel et al. (2004). However, economic evaluation studies of precision agriculture technologies with automatic assistance systems, drones or sensors and direct injection have not been conducted so far. In the research project 'AssSys' (assistance system for site-specific applications of pesticides, Pohl et al., 2021), the precision agriculture technology described and the application assistant developed were investigated and evaluated economically.

The following research questions were in the focus of the study:

(1) Which cost savings can be achieved by site-specific applications of herbicides and fungicides?

(2) What other economic advantages result from the possible cost savings?

(3) How high are investment costs of the described precision agriculture technology?

(4) Can pesticide cost savings compensate for investment costs for the precision agriculture technology?

(5) How large is the minimum area where precision agriculture is applied annually for farmers to cover investment costs?

\section{Materials and methods}

The economic assessment of site-specific pesticide applications with automatic application assistant, drone or sensors and direct injection was carried out by means of a scenario analysis. The scenario analysis was based on field trials in 2018 and 2019 for a model farm in northern Germany. For this purpose, two scenarios of site-specific pesticide applications including herbicide and fungicide treatments were compared to a scenario with uniform treatment after IPM. While herbicide applications were part of the field trials, fungicide applications were based on hypothetical assumptions. In the following, the field trials are described, followed by the methods of economic assessment 
and the assumptions of the scenario analysis. Finally, the method for calculating the minimum application area is described.

\section{Field trials with site-specific herbicide applications}

To gain realistic data for the scenario analysis, field trials were conducted at three locations (Sickte, Osterwieck and Cappeln) in the Northwest of Germany in 2018 and 2019 on six experimental plots (geodata in Table 1). The total area of field plots covered 32 ha. Winter wheat, spring wheat and winter barley were cultivated. The soils of the experimental sites covered the spectrum from sandy to clay loam and represented a middle to good soil quality. As the creation of application maps is relying on exact previous weed monitoring, either by the farmer himself or automatically by sensor or drone, weed monitoring was conducted as (1) standard procedure according to IPM (Barzman et al., 2015), (2) camerabased and (3) drone-based in the field trials. Weed detection by camera and drone was carried out using a high-resolution RGB camera. The drone served as a carrier system. For the spatial analysis, a point grid with a grid size of $12 \times 12 \mathrm{~m}$ was used instead of the entire area. The RGB images were analysed with a self-developed artificial intelligence, using the colour and shape recognition method (Wellhausen et al., 2020).

The field trials with site-specific herbicides were conducted as an example for one season to test the newly developed precision agriculture technologies regardless of representativeness and reproducibility. They were not based on a special design. A detailed description of each treatment in each investigated plot can be found in Table 1. The size of the site-specific application area was based on the detected weed species. Figure 3 presents an example of an application map created for site-specific applications of herbicides based on weed maps (Figs. 1 and 2).

The field trial plot sizes ranged from 2.3 to 7 ha in the conventional applications and from 1 to 6.37 ha in the site-specific applications (sum of the site-specifically treated areas). Based on weed monitoring (Figs. 1 and 2), Fig. 3 presents an example of an application map created for site-specific applications of herbicides at the experimental site 'Sickte $1+2$ ' in 2019. The experimental site was divided into three subplots (Fig. 3). Direct injection was used here to apply the herbicides 'Broadway' and 'Ariane C' in one tractor pass using two tanks, application map and automatic spraying system (details in line 6 of Table 1). Subplot 1 was treated with 'Broadway' (yellow colour) and subplot 2 with 'Ariane C' (red colour), whereas the remaining (white) area was not treated (Fig. 3). Only $27 \%$ of the total field area was applied with herbicides in this field plot.

The share of applied subplots at the experimental sites showed a wide range from 27 to $100 \%$ of treatment area according to the individual weed situation in each plot (Table 1). The herbicide savings ranged from 5 to $33 \%$. Due to the applied tank mixtures in the conventional applications (Table 2), the number of tractor passes did not result in higher costs than in the site-specific applications. (A detailed overview of the applied pesticides, application rates and active substances in the field trials is shown in the Supplementary Material.)

\section{Hypothetical site-specific fungicide applications based on monitoring results}

Due to the absence of field trials, the selection of subplots for site-specific fungicide applications was based on a spatial analysis scheme and georeferenced stem base disease 


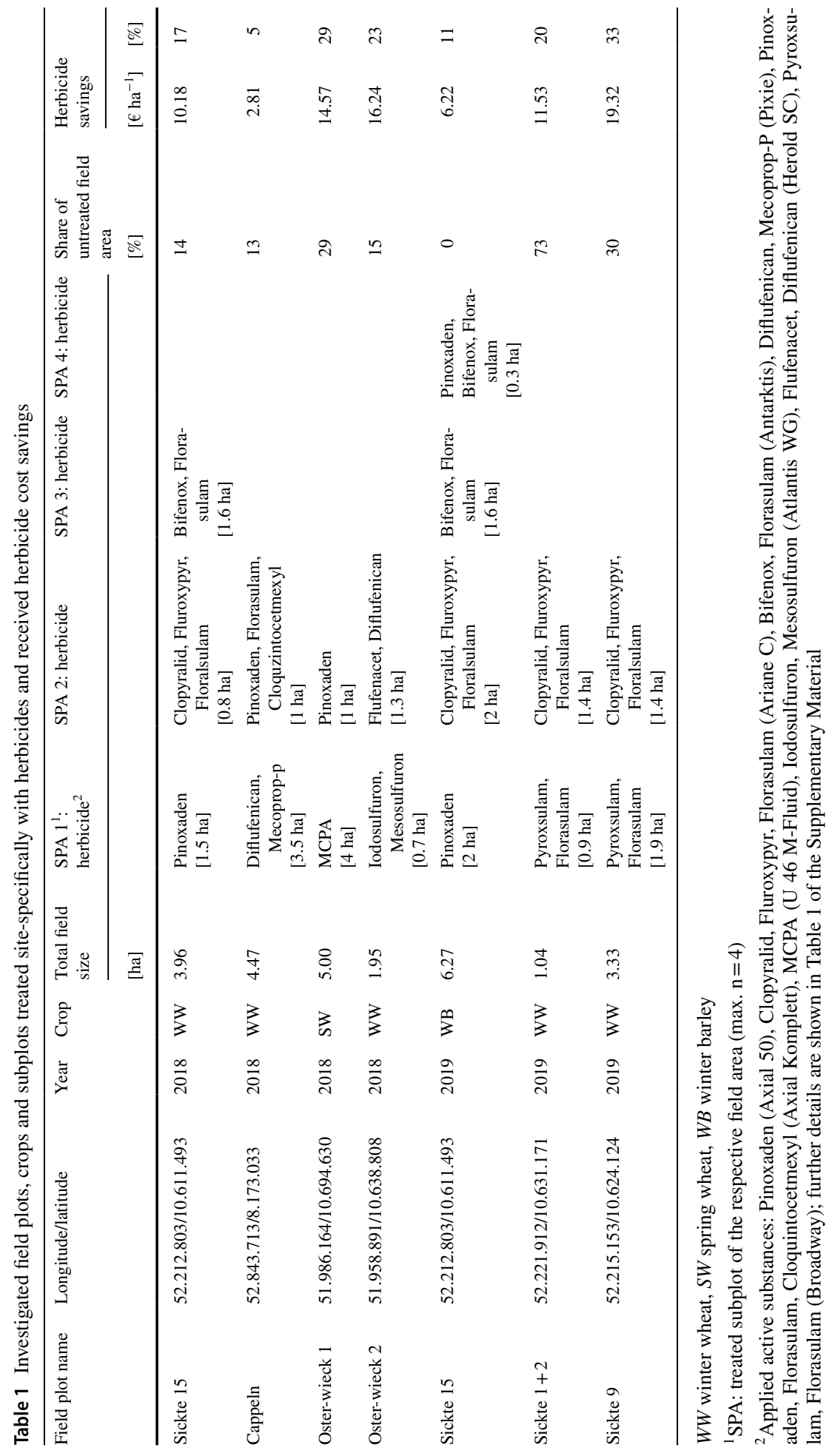


Fig. 1 Weed distribution at the experimental site 'Sickte 15 ' in 2019 showing some details of SPA $1=$ area identified with $>30$ dicotyledonous weeds per square metre

Fig. 2 Weed distribution at the experimental site 'Sickte 15 ' in 2019 showing some details of SPA $2=$ area identified with $>6$ monocotyledonous weeds per square metre
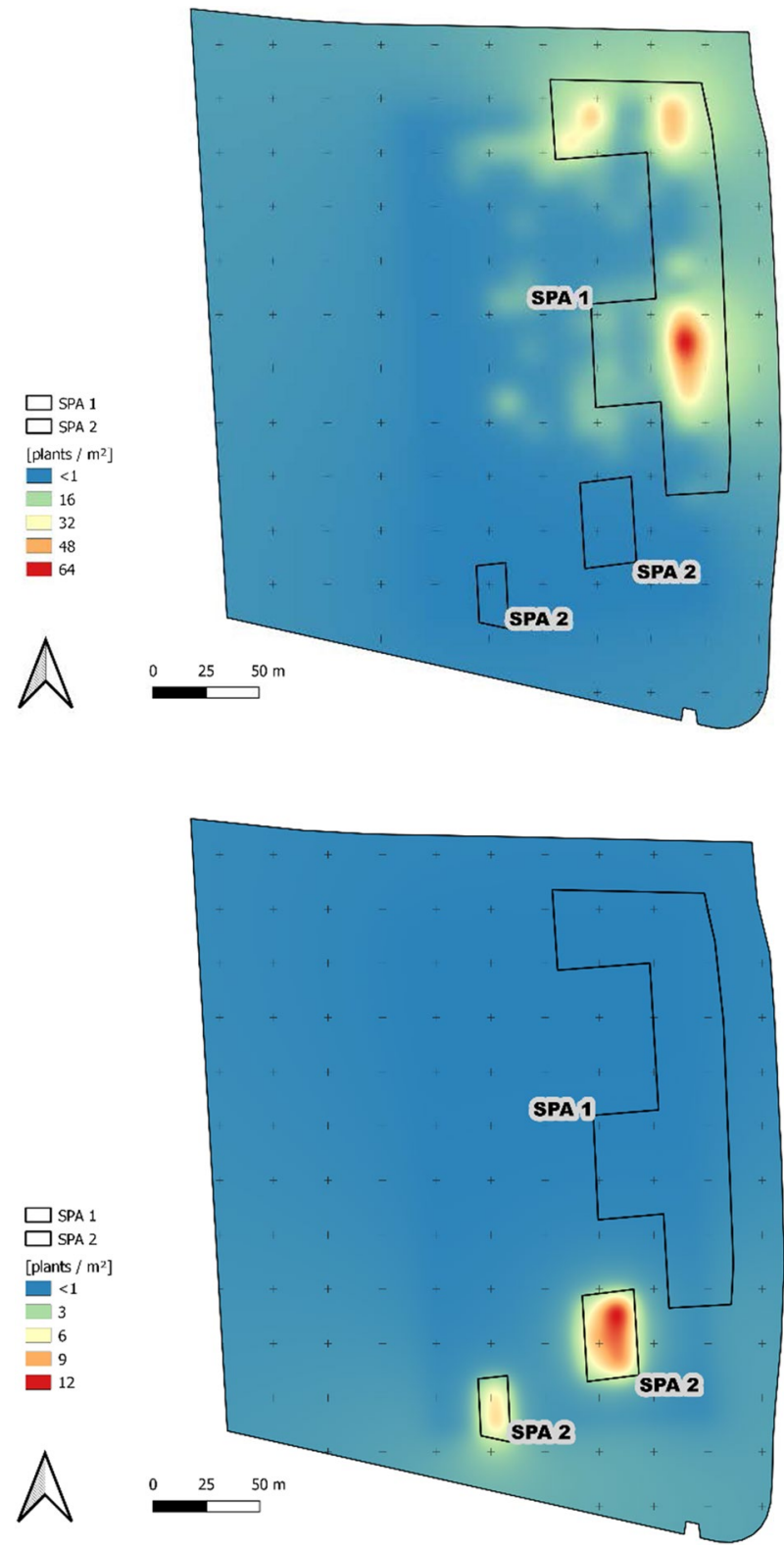

monitoring data (Herrmann et al., 2020). The monitoring data were gathered during milk ripening in several winter wheat fields collecting ten or twenty tillers per point in the form of a sampling grid and assessing stem base disease infestation visually. Here, the monitoring data for stem base disease with 189 monitoring points on the field plot 'Niederweide' (longitude: 8.194287771 , latitude: 49.8753377 ) with a total field plot size of 4.15 ha are shown. In combination with the spatial analysis scheme of Herrmann et al. (2020), subplots of low, medium and high disease infestation (Fusarium spp. and Microdochium 
Fig. 3 Example application map of the experimental site 'Sickte 1+2' in 2019 showing SPA $1=$ area treated with the herbicide 'Broadway' and SPA $2=$ area treated with the herbicide 'Ariane C'
Table 2 Herbicide tank mixtures used in the conventional applications

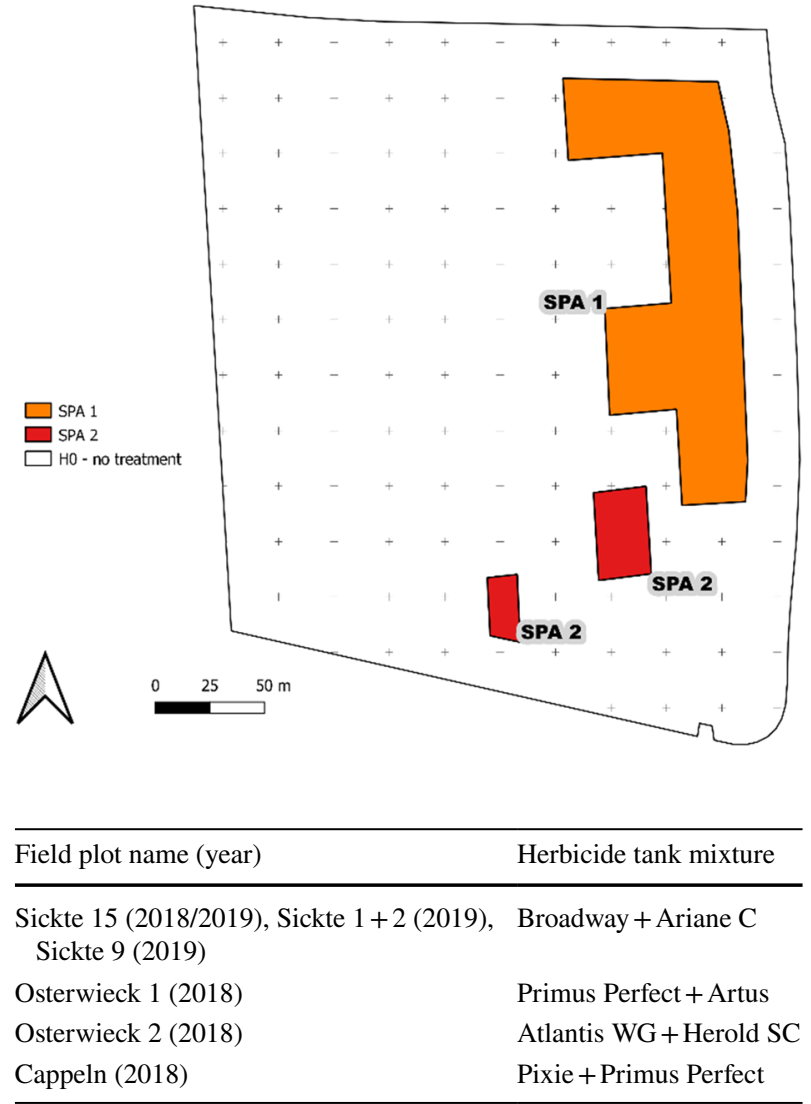

nivale, Fig. 4) were identified. The field plot area with low disease infestation resulted in $18 \%$ of the total plot size, the field plot area with medium disease infestation in $48 \%$ of the total plot size and the field plot area with high disease infestation infection in $34 \%$ of the total plot size (Table 3). For calculations of fungicide application costs, these field plot areas were assigned to three subplots F0 (average Bockmann-value ${ }^{1}$ of 15), SPA 1 (average Bockmann-value of 19) and SPA 2 (average Bockmann-value of 22). Due to low disease infestation, F0 (white zone) was identified as no treatment area. Given a well-known effect against stem base disease, the fungicide 'Input Classic' (a.i.: $300 \mathrm{~g} \mathrm{l}^{-1}$ spiroxamine $+160 \mathrm{~g}$ $1^{-1}$ prothioconazole) was chosen for SPA 1 (orange zone) and SPA 2 (red zone). The conventional alternative comprised fungicide application on the total field plot (4.15 ha). It has to be emphasised that the monitored field plot areas can only be seen as an approximation for the selection of subplots in hypothetical application scenarios. Recommendations for agricultural practice on selection of fungicides cannot be given based on this method indicating only relative spatial distribution of stem base disease infestation.

1 see Biological Federal Institute (1996). 
Fig. 4 Zones of infestation of stem base disease at the experimental site 'Niederweide' in 2018, (FO area of low disease infestation with average Bockmann-value of 15 ; no treatment; SPA 1 area of medium disease infestation with average Bockmann-value of 19) and SPA 2 area of high disease infestation with average Bockmann-value of 22)

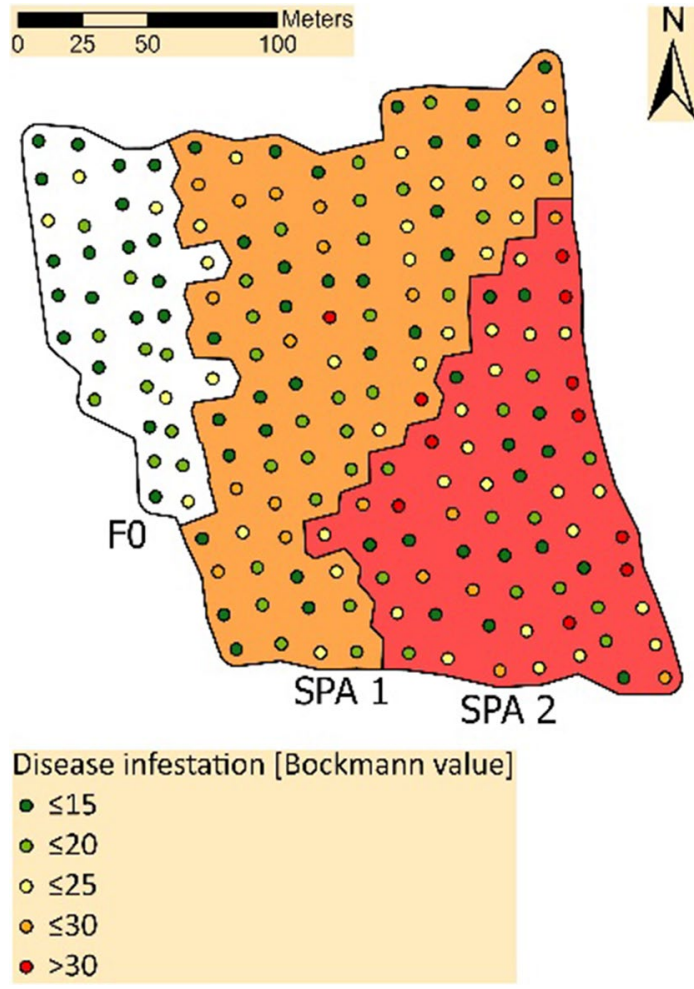

Table 3 Subplots of hypothetical site-specific fungicide applications and share of applications areas in winter wheat (2018)

\begin{tabular}{|c|c|c|c|c|}
\hline Field/subplot & $\begin{array}{l}\text { Total field size } \\
\text { [ha] in CPA }\end{array}$ & $\begin{array}{l}\text { Assigned sub- } \\
\text { plots [ha] in SPA }\end{array}$ & Theoretically applied fungicide & $\begin{array}{l}\text { Hypothetical } \\
\text { application area } \\
{[\%]}\end{array}$ \\
\hline CPA & 4.15 & - & Spiroxamine, Prothioconazol ${ }^{1}$ & $100 \%$ \\
\hline F0 & & 0.74 & No treatment & $18 \%$ \\
\hline SPA 1 & & 1.98 & Spiroxamine, Prothioconazol & $48 \%$ \\
\hline SPA 2 & & 1.42 & Spiroxamine, Prothioconazol & $34 \%$ \\
\hline
\end{tabular}

$C P A$ conventional pesticide applications, $S P A$ site-specific pesticide applications

${ }^{1}$ Input classic

\section{Economic assessment}

Based on partial budgeting methods, extended gross margins were used as economic key performance indicator (Mußhoff \& Hirschauer, 2016; Schroers et al., 2010). Herbicide and fungicide costs were 'extended' by permanent labour costs to allow for comparison of the investigated application strategies. They were calculated for each crop in the respective field plot (Table 4). In addition to the revenues received, the operating costs 
Table 4 Calculation of extended gross margins (after Mußhoff \& Hirschauer, 2016; Schroers et al., 2010)

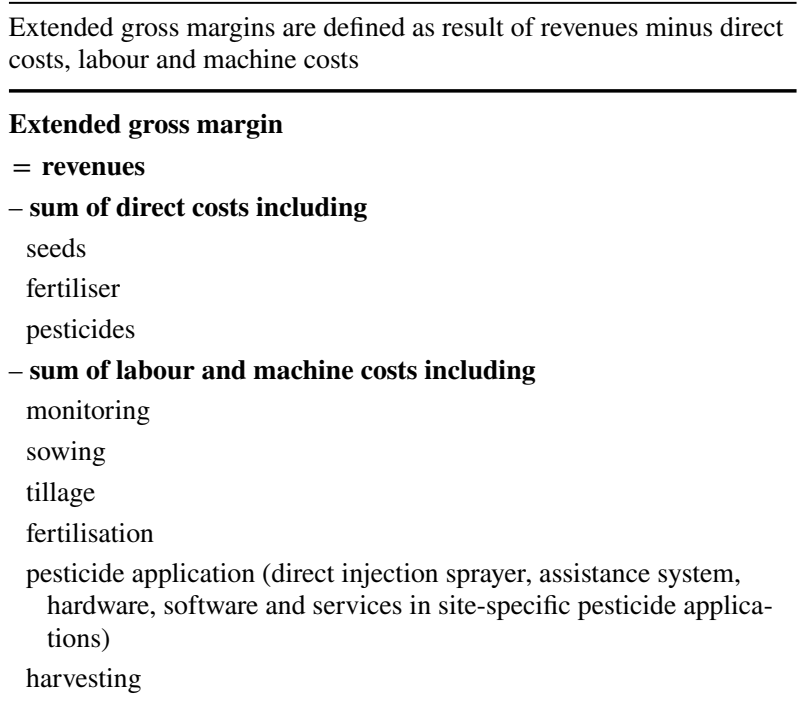

for monitoring, sowing, tillage, fertilisation, pesticide application and harvesting including machine (conventional and new precision agriculture technologies with hardware, software and service costs) and labour were considered. For the field work processes and tractor passes, variable and permanent workforce was considered (Schroers et al., 2010). Labour costs of permanent employees were considered since they are directly attributable to the respective field work process and are therefore an influencing factor.

In order to compare the different site-specific scenarios with conventional application, investment costs of the precision agriculture technology were included as annual labour and machine costs of herbicide and fungicide application costs. For the calculation of extended gross margins $\mathrm{ha}^{-1}$, it is necessary to account for machine and labour costs on an annual level (by annuity calculation). For the calculation of annuity, a discount rate of $3 \%$ for tied capital was assumed and 10 years of operating life. Annual labour and machine costs were calculated within the conventional scenario by the German standard fieldwork calculator (KTBL, 2018/2019). For the site-specific scenarios, only the annual machine costs were derived from annual investment costs (for the new technologies). Costs for maintenance, insurance, repair and labour were added from standard KTBL data. As a result, the annual investment costs (for site-specific technology) and conventional costs were comparable and included in the calculations of the extended gross margin.

This is a well-established procedure in economic valuation of pesticide measures due to the fact that the costs of pesticide measures do not only depend on the price of the applied herbicides or fungicides but also on the individual labour and machine costs of tractor passes to conduct the measures. The costs of tractor passes are dependent on the assumptions made e.g. on field size, farm-field distance, diesel price and price of one working hour. In order not to underestimate the technical costs, maximum rates were considered. Labour costs of monitoring in the site-specific applications were assumed to comprise three times the monitoring labour time in conventional applications. Inputs (see direct costs in Table 4) and their applied rates were based on the field trials, except for fungicides. 
Site-specific applications of fungicides were based on monitoring results described above and conducted only hypothetically. Besides the investment costs of the precision agriculture technology used in the scenarios, extended gross margins (as described in Table 4) were calculated to compare the different scenarios.

\section{Scenario analysis}

For the conventional application scenario, two sprayings per year were assumed, conducted in fall and in spring. For site-specific applications, only one application was assumed in spring due to the reliable size of the weeds for automated weed detection in this season. Labour and machine costs for monitoring, sowing, tillage, fertilisation, pesticide applications and harvesting were determined according to KTBL (2018/2019) and are based on a model farm.

This model farm was assumed to have a size of 1000 ha with an average field size of $10 \mathrm{ha}$. The assumptions were based on the typical (average) farm size of a farm in Lower Saxony, where the majority of field trials were conducted. The model farm was developed together with experts in the project, which suggested these farm characteristics for applying precision agriculture technologies. Published data on field sizes is not available in German agricultural statistics. Only estimations via ATKIS administrative data were available. The official topographic cartographic information system (ATKIS) of the Working Group of the Surveying Authorities of the Federal States is a nationwide standardized data model for the provision of topographic survey information in Germany. Actual ATKIS data (2013, 2017, and 2021) and a query on average field sizes revealed an average field size of 10 ha for Germany (Röder et al., 2018; Schneider \& Wagner, 2008).

A 1000 ha farm size is not typical for German farms, but typical for farms applying new technologies such as site-specific pesticide applications. Such farms exist in the North-East of Germany. According to experts in the 'AssSys' project, farms with 1000 ha farm size are typical for those farms using or willing to use precision agriculture technologies. There is no statistical data or literature for Germany to confirm this expert assessment. However, the farm size was not important for calculations, since the extended gross margins were calculated per hectare and not for a whole farm. In contrast, field size is important for machine calculations and that's why calculations were based for this point on (field size) experts, literature and ATKIS estimation.

The average annual temperature was $9.7^{\circ} \mathrm{C}$, and the average annual precipitation was $626 \mathrm{~mm}$. It was assumed that a tractor with a farm management information system (FMIS), yield mapping, DGNSS and parallel driving system was available and used. The FMIS is used to apply the digital information of the respective field and the detected weeds to the spraying system and to automatically control the nozzles via using application maps. A farm-to-field distance of $5 \mathrm{~km}$ and a water application rate of $300 \mathrm{l} \mathrm{ha}^{-1}$ were assumed for herbicide and fungicide applications. Diesel costs of $0.75 € 1^{-1}$ and labour costs of $20 € \mathrm{~h}^{-1}$ were considered (KTBL, 2018/2019). Herbicide and fungicide prices were based on current trade price lists for crop protection products (Agravis Raiffeisen, 2019, 2020). Producer prices, seed and fertiliser costs were based on agricultural statistics (Agricultural Market Information Company, 2019, 2020; Federal Ministry of Food \& Agriculture, 2019, 2020). If yield data were not available for a field plot, data from agricultural statistics were used for further calculations (Federal Ministry of Food \& Agriculture, 2019, 2020). A crop protection trailed sprayer with $27 \mathrm{~m}$ working width, 


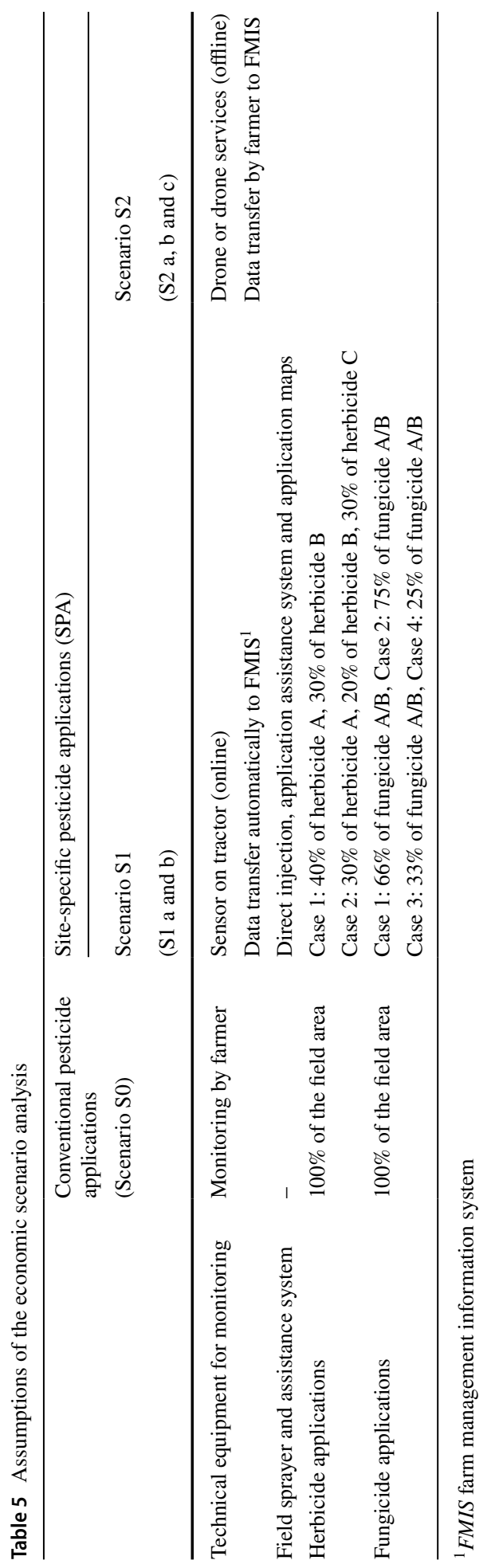


40001 tank volume, $83 \mathrm{~kW}$ machine power was used to determine labour and machine costs in the conventional application scenarios (KTBL, 2018/2019). For the calculation of labour and machine costs in the site-specific scenarios, a crop protection sprayer with direct injection and two chambers with $27 \mathrm{~m}$ working width, 60001 tank volume and $70 \mathrm{~kW}$ machine power were assumed based on the technology used in the field trials.

In detail, three scenarios were designed. The first scenario ('S0') simulates conventional methods of monitoring and pesticide applications at $100 \%$ of the field area according to IPM methods (conventional application). The scenarios ' $\mathrm{S} 1$ ' and 'S2' simulate site-specific monitoring and application strategies (Table 5). In both scenarios, application maps are used to support site-specific applications of herbicides and fungicides. In scenario $\mathrm{S} 1$, site-specific applications relied on application maps generated from online softwareanalysis of sensor data (H-sensor for weed detection and P3-sensor to measure growth height, biomass and number and position of leaf layers in preparation of fungicide treatments, Agricon, 2020). In scenario S2, offline RGB image capture by a drone was applied. Two additional scenario alternatives ( $\mathrm{S} 1 \mathrm{a}$ and $\mathrm{b}$ ) were assumed in $\mathrm{S} 1$, and three additional alternatives (S2 a, b, and c) in S2.

Scenario S1 (a) included the acquisition of the direct injection, the application assistance system and sensors. Scenario S1 (b) differed from the first scenario only in the detail that an existing standard field-sprayer of $27 \mathrm{~m}$ working width was upgraded to a direct injection sprayer instead of a new purchase. The scenario $S$ (2a) simulated the acquisition of the direct injection, the application assistance system and a drone. Scenario S2 (b) differed from the S2 (a) only in the standard field-sprayer upgrade (27 m working width) instead of purchasing a (new) direct injection sprayer. In scenario S2 (c), upgrade costs for a standard field-sprayer of $27 \mathrm{~m}$ working width, investment costs of the application assistance system and a drone service by an external service provider were simulated.

\section{Minimum application area (Break-Even-Point)}

To derive information on the minimum area, farmers have to apply with the described precision agriculture technology to cover investment costs, the Break-Even-Point (BEP) was calculated for the model farm. It includes the annual investment costs of direct injection, the value of saved pesticide costs by site-specific applications and the additional labour costs of monitoring fields in preparation for site-specific treatments. Calculations based on Eq. (1) with $30 \%, 50 \%$ and $70 \%$ of herbicide savings are shown in the results section (after Lettner et al., 2001).

$$
\mathrm{BEP}=\frac{\mathrm{K}_{\mathrm{T}}}{\mathrm{E}-\mathrm{K}_{\mathrm{A}}}
$$

where $\mathrm{K}_{\mathrm{T}}$ are the annual investment costs (annuity of investment costs) of the field sprayer used and $\mathrm{E}$ is the value of pesticide costs saved in $€ \mathrm{ha}^{-1}$ year $^{-1}$, and $\mathrm{K}_{\mathrm{A}}$ represents the additional labour costs per year (e.g. for monitoring in preparation for site-specific applications). For instance, the lower the annual technical costs and the additional labour costs per year, the smaller the resulting minimum application area for the farmer. 


\section{Results}

In this section, results of the economic assessment are presented. First, the investment costs of the application assistant, drone or sensors and direct injection are shown as an important input for the scenario analysis. In the second part, results of the scenario analysis are presented. Finally, the minimum application area (BEP) of the model farm is shown.

\section{Investment costs of the application assistant and crop protection sprayer with direct injection}

Overall, the annual investment costs of the site-specific scenarios vary between 21 and 37 $€ \mathrm{ha}^{-1}$ depending on the level of technical equipment. The most expensive technique is the site-specific application scenario with application assistant, two sensors and a new direct injection sprayer (S1 a; Table 6). The most favourable economic scenario is the one with application assistant, external drone services and sprayer upgrade (S2 c). The difference between the average of the site-specific application scenarios and the conventional scenario results was $17 € \mathrm{ha}^{-1}$.

The investment costs of sensors for weed detection and detection of crop density are the most expensive at $56000 €(\mathrm{~S} 1 \mathrm{a}$ and b) compared to the investment costs of a drone at approximately $9000 €(\mathrm{~S} 2 \mathrm{a}$ and $\mathrm{b}$ ). Maximum investment costs for the acquisition of a new direct injection spraying system were assessed at $140000 €(\mathrm{~S} 1$ a and S2 a). For the scenarios with sprayer upgrade instead of new purchase, a standard sprayer according to KTBL of 27 m working width equipped with two additional nozzle lines, resulted in investment costs of $98000 €(\mathrm{~S} 1 \mathrm{~b}, \mathrm{~S} 2 \mathrm{~b}$ and $\mathrm{c})$. The annual costs of the application assistant resulted in $0.17 € \mathrm{ha}^{-1}$, including a basic package for hosting service, software updates and user support. Within the conventional application scenario, only annual labour and machine costs of monitoring and pesticide applications of $13 € \mathrm{ha}^{-1}$ were calculated (without direct injection, application assistant and sensor or drone).

\section{Scenario analysis}

Herbicide and fungicide cost calculations clearly indicate the economic advantage of the precision agriculture technology used. They are lower in the investigated site-specific scenarios compared to the conventional scenario (Fig. 5). On average, over the years and field plots examined, the herbicide costs including labour and machine costs of monitoring and applications, were $169 € \mathrm{ha}^{-1}$ in the conventional application scenario and $58 € \mathrm{ha}^{-1}$ in the site-specific scenarios, revealing $66 \%\left(111 €\right.$ ha $\left.^{-1}\right)$ cost savings. Fungicide costs result on average in $196 € \mathrm{ha}^{-1}$ in the conventional scenario and $121 € \mathrm{ha}^{-1}$ in the site-specific scenarios. This shows again a cost advantage of the site-specific applications which amounts to $75 € \mathrm{ha}^{-1}$ or $38 \%$. The major cost savings in site-specific scenarios were observed for herbicides and fungicides in the drone scenario S2 c with $71 \%$ for herbicides and $43 \%$ for fungicides.

Extended gross margins show clearly the economic advantage of the site-specific application scenarios, lying 18 to $22 \%$ above the conventional scenario (Table 7). On average, over the years and field plots, the extended gross margin resulted in $631 € \mathrm{ha}^{-1}$ in the conventional scenario and $787 € \mathrm{ha}^{-1}$ in the site-specific scenarios. This reveals an average 


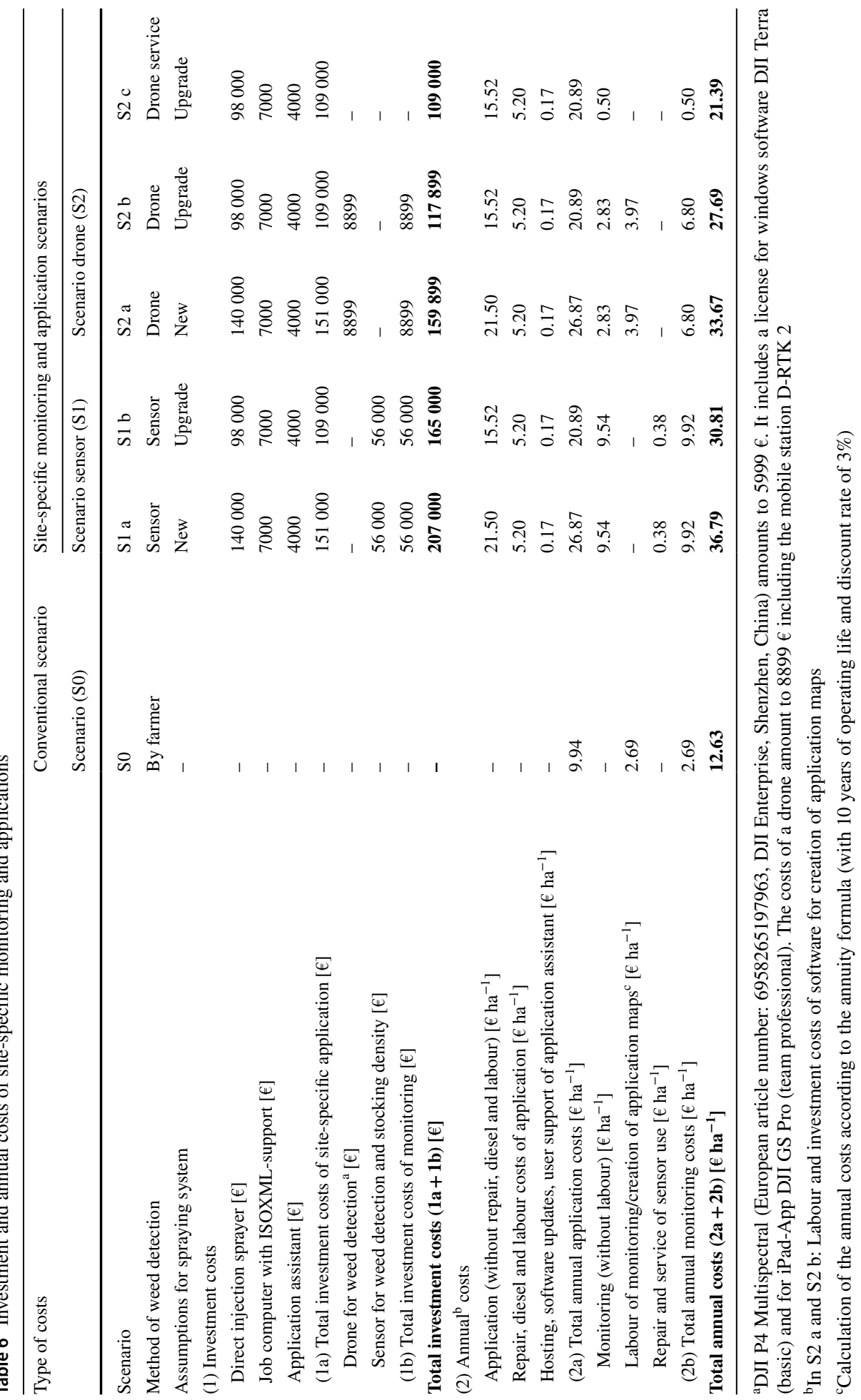




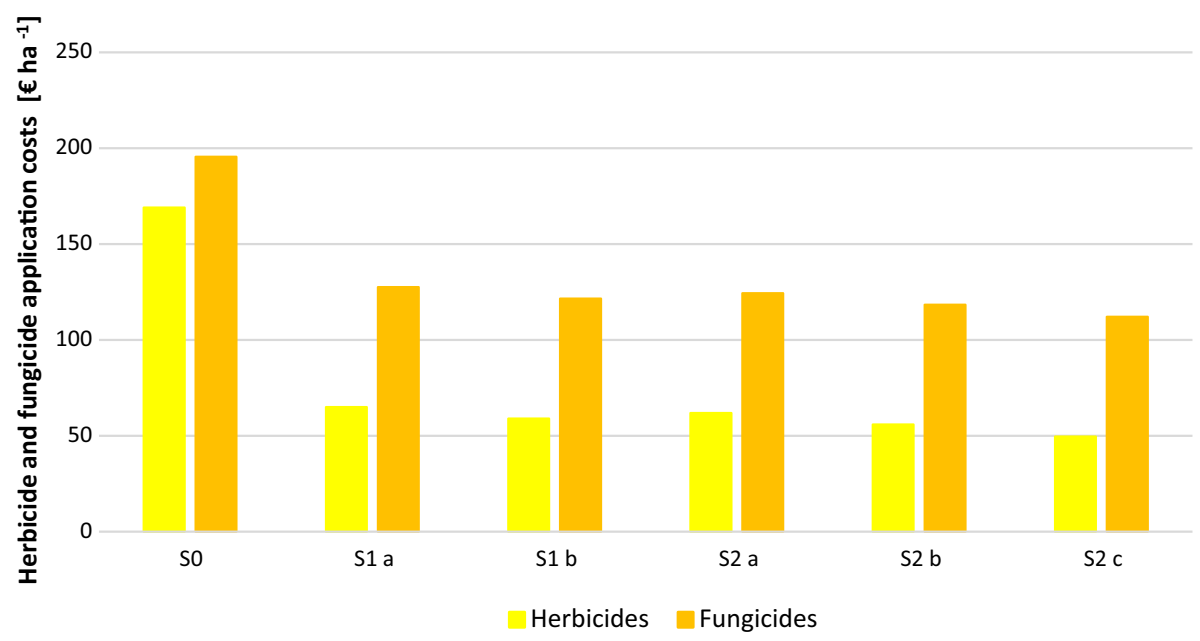

Fig. 5 Herbicide and fungicide application costs including labour and machine costs of monitoring and applications of the conventional scenario (S0) and site-specific applications scenarios [S1 $a$ direct injection (DIS) + application assistant (AAS) + sensor, S1 $b$ upgrade to DIS + AAS + Sensor, $S 2 a$ DIS + AAS + drone, $S 2 b$ upgrade to DIS + AAS + drone, $S 2 c$ upgrade to DIS + AAS + drone service]

Table 7 Extended gross margins of the conventional application scenario and the site-specific application scenarios

\begin{tabular}{|c|c|c|c|c|c|c|}
\hline & \multirow{2}{*}{$\begin{array}{l}\text { Conventional } \\
\text { scenario } \\
\text { (S0) }\end{array}$} & \multicolumn{5}{|c|}{ Site-specific application scenarios } \\
\hline & & $\mathrm{S} 1 \mathrm{a}$ & $\mathrm{S} 1 \mathrm{~b}$ & $\mathrm{~S} 2 \mathrm{a}$ & $\mathrm{S} 2 \mathrm{~b}$ & $\mathrm{~S} 2 \mathrm{c}$ \\
\hline Field plot, year, crop & $€ \mathrm{ha}^{-1}$ & & & $€ \mathrm{ha}^{-1}$ & & \\
\hline Sickte 15 (2018) WW & 501 & 756 & 768 & 762 & 774 & 786 \\
\hline Cappeln (2018) WW & 371 & 477 & 489 & 484 & 496 & 508 \\
\hline Osterwieck 1 (2018) SW & 569 & 696 & 708 & 702 & 714 & 726 \\
\hline Osterwieck 2 (2018) WW & 459 & 601 & 613 & 607 & 619 & 631 \\
\hline Sickte 15 (2019) WB & 834 & 701 & 713 & 707 & 719 & 732 \\
\hline Sickte $1+2$ (2019) WW & 843 & 1211 & 1223 & 1218 & 1230 & 1242 \\
\hline Sickte 9 (2019) WW & 838 & 973 & 985 & 979 & 991 & 1004 \\
\hline Mean & 631 & 773 & 785 & 780 & 792 & 804 \\
\hline Difference $\mathrm{S} 1 / \mathrm{S} 2$ to $\mathrm{S} 0$ & & 142 & 154 & 149 & 161 & 173 \\
\hline Economic advantagec $^{\mathrm{a}}[\%]$ & & 18 & 20 & 19 & 20 & 22 \\
\hline
\end{tabular}

S1 $a$ direct injection (DIS) + application assistant (AAS) + sensor, S1 $b$ upgrade to DIS + AAS + sensor, $S 2 a$ DIS + AAS + drone, $S 2 b$ upgrade to DIS + AAS + drone, $S 2 c$ upgrade to DIS + AAS + drone service, $W W$ winter wheat, $S W$ spring wheat, $W B$ winter barley

${ }^{a}$ The difference in extended gross margins of site-specific scenarios (S1 or S2) and the conventional scenario (S0) in \%

economic advantage of $156 €$ ha $^{-1}$ or $20 \%$ of the site-specific scenarios compared to the conventional one in terms of the resulting extended gross margins. The results demonstrate that the site-specific pesticide applications were also economically beneficial taking into 


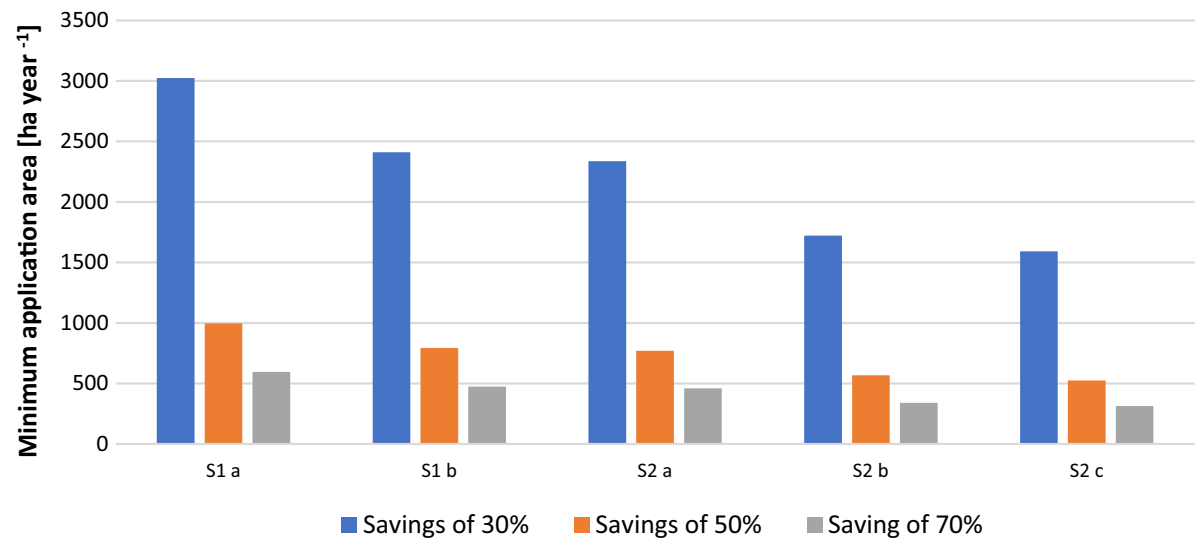

Fig. 6 Minimum application area of the site-specific application scenarios $\left[\begin{array}{lll}S & a \\ \text { direct injec- }\end{array}\right.$ tion (DIS) + application assistant (AAS) + sensor, $S 1 \quad b$ upgrade to DIS + AAS + Sensor, $S 2 \quad a$ DIS + AAS + drone, $S 2 b$ upgrade to DIS + AAS + drone, $S 2 c$ upgrade to DIS + AAS + drone service]

account the investment costs of precision agriculture technology. The extended gross margins in 2019 were slightly higher in winter wheat compared to 2018 due to higher yields in 2019. However, the most influencing factor in the study is, besides the cost savings in herbicides in the site-specific application scenarios, the relatively low costs of the external drone services in $\mathrm{S} 2 \mathrm{c}$.

Compared with the savings of pesticide costs in the site-specific application scenarios, the precision agriculture technology costs were not substantial. The scenario with the highest pesticide savings compared to $\mathrm{S} 0$ turned out to be scenario $\mathrm{S} 1 \mathrm{c}$, where investment costs were also the lowest. The scenario with the highest pesticide costs was $\mathrm{S} 1 \mathrm{a}$, where also the highest investment costs appeared.

\section{Minimum application area of the model farm}

Finally, a core element of farmers' decision on whether to apply a new procedure like the precision agriculture technology or not, is the question as to whether costs can be compensated by the individual farm. As described in the methodology section, the BEP was calculated to answer this question (Fig. 6). For $70 \%$ of pesticide cost savings in the site-specific application scenarios, the minimum application area necessary to compensate for the precision agriculture technology costs is estimated between 314 ha per year (drone scenario S2 c) and 597 ha per year (sensor scenario S1 a). If the pesticide cost savings are only about $30 \%$, the necessary minimum area is 1593 ha per year for the drone scenario S2 c and 3024 ha per year for the sensor scenario S1 a. For the model farm considered in the scenario analysis, comprising 1000 ha farm size, from average savings of 50\% in site-specific applications upwards, the investment in the precision agriculture technology presented is profitable. 


\section{Discussion}

The study revealed potential cost savings by site-specific applications of herbicides and fungicides. Higher extended gross margins resulted in an economic advantage for site-specific applications compared to conventional treatments. Investment costs of the described precision agriculture technology were presented in detail. Furthermore, the scenario analysis showed that investment costs are affordable with the investigated assumptions. Finally, the minimum application area of site-specific pesticide applications was presented which is necessary to compensate for the investment costs of the required technical equipment.

Adjustment of farmers to precision agriculture technologies is not progressing as fast as predicted in the EU (Rasmussen et al., 2020, JRC, 2014, McBratney et al., 2005). Only about $30 \%$ of German farmers are currently using site-specific pesticide and fertiliser applications (Rohleder et al., 2020). Currently, $40 \%$ of German farmers complain about a lack of 'know how' in precision agriculture technologies (Rohleder et al., 2020). After JRC (2014), farmers complain that they are not able to use independent advisory or consultancy services e.g. offered by government bodies, co-operatives and farmer associations.

Investment grants are necessary to improve farmers' digital skills, as well as advisory services and the respective infrastructure, which may be funded under the European agricultural fund for rural development (Fortuna \& Michalopoulos, 2020). In the funding period from 2021 to 2024, grants for German farmers within the 'Investment and Future Programme Agriculture' of up to $40 \%$ with maximun $250000 €$ were awarded for small and medium enterprises. Multi chamber direct injection field sprayers, as used in the field trials described above, were part of the investment programme (Rentenbank, 2021). Actually, farmers seem to be very keen to take advantage of these funding opportunities, as announcements had to be paused due to very high demand (Rentenbank, 2021).

\section{Pesticide savings and potential environmental effects}

Precision agriculture technologies have been described to support sustainable agriculture (e.g. Bongiovanni \& Lowenberg-DeBoer, 2004) including the successful reduction of pesticide use and risks. Site specific herbicide applications have been widely reported to save pesticides when compared to conventional treatment of the complete area by $30 \%$ up to 90\% (Gerhards \& Christensen, 2003; Hufnagel et al., 2004; Lettner et al., 2001; Nordmeyer et al., 2003; Timmermann et al., 2003). An economic assessment of site-specific pesticide applications with automatic application assistant and sensor or drone, however, has not been conducted before. Moreover, the application of direct-injection field sprayers, which has been included in the investigated assessment with full investment and labour costs, represents a new technology of precision agriculture. Timmermann et al. (2003) already suggested such a system for optimizing site specific and precise weed management. The herbicide savings achieved ranged in the presented study between 50 and 57\% and are in line with the above findings from the literature (Barroso et al., 2003; Korres et al., 2019; Lettner et al., 2001; Oebel \& Gerhards, 2005; Swinton, 2005; Takăcs-György \& Takăcs, 2009; Timmermann et al., 2003).

To the authors' knowledge there are so far no other publications on estimations of extended gross margins in site-specific pesticide applications for comparison of the results. Ancev et al. (2004) designed a framework to account for broader benefits and beneficial 
aspects of precision agriculture based on economic, environmental and agronomic aspects such e.g. yield effects.

In this study, in most cases, no additional yield increases on the plots, treated sitespecifically, could be determined. Only at the field plot 'Sickte 15 ' in 2019, the yield was $1.4 \mathrm{t}(16 \%)$ above the conventional application field plot. In other studies, yield increases by precision agriculture technologies in weed management could also not be clearly observed either in field trials or in model estimations (Gerhards et al., 2011; Hamouz et al., 2013, 2014). Hamouz et al. (2013) found that site-specific weed management applied to winter cereals and winter oilseed rape had no significant effect on crop yields. On the other hand, Hamouz et al. (2014) found negative correlation coefficients between plant densities in site-specific weed management treatments indicating that some weeds e.g. Apera spica-venti did not establish a long-term soil seed bank. This may have positive effects on future yields. Gerhards et al. (2011) attributed yield effects to weed competition using a linear mixed model. However, when a conventional plot experiment was set up in the same field of the site-specific treatments, no statistically significant grain yield difference between the treatments was found (Gerhards et al., 2011). Hamouz et al. (2014) state that even if weed control is intensive, an increase in some weed populations may occur in a field due to repeated cultivation of the same crop. However, it should be considered, that weed population dynamics are affected not only by herbicide application but by many other factors, such as crop rotation and soil conditions (Hamouz et al., 2014). Thus, it seems to be difficult to attribute yield effects clearly to site-specific herbicide treatments. Finally, Hamouz et al. (2014) emphasised that crop rotation should be considered as an integral part of each weed control system due to seed persistence in the soil. Additional studies on yield effects of strategies with reduced pesticide use could be helpful, since potential yield increases represent additional economic benefits for farmers to apply precision agriculture technology (Christensen et al., 2009).

The scenario analysis revealed that site-specific fungicide applications saved costs of $38 \%$ (or $75 € \mathrm{ha}^{-1}$ ) compared to conventional applications. Dammer and Ehlert (2006) and Dammer et al. (2009) found that about $20 \%$ of the applied fungicide amount could be saved in barley and wheat by adapting the application to the stand density. Since the results from the scenario analysis carried out refer to the fungicide costs in dependence of the applied share of area while the cited literature on the quantity of fungicides saved on $100 \%$ of the area, the results are not completely comparable to each other. However, the dimension of the saving potential for field trials with fungicides could be shown. A process-based model of Whetton et al. (2018) resulted in fungicide reductions of $26 \%$ and $£ 17.7 \mathrm{ha}^{-1}$ (20.78€ $\mathrm{ha}^{-1}$ ) per field potential gross (profit) saving when compared to conventional applications. The model was applied as a decision tool for farmers to optimise their individual decisions on fungicide applications. Another study, carried out in vineyard and apples, showed that fungicide savings reached from 10 to $35 \%$ compared to conventional sprayings (Tona et al., 2018). A direct comparability to the scenario analysis is also not possible, but it clearly shows that site-specific fungicide application technologies can be profitable over conventional sprayings.

Also, in the treatment of fungal infestations, the adjustment to precision agriculture has to be based on precise data on the condition of the crop and the spatial distribution of the disease considered (Jambhulkar \& Meshram, 2013; Mahlein et al., 2012). The characterisation of the spatial distribution of the pathogen or disease is complex, manual field surveys are not a practicable solution due to the large amount of work involved (Dammer \& Ehlert, 2006). In contrast, sensor-based methods offer the possibility of deriving the distribution 
of the respective disease on the basis of the distribution of associated pest symptoms in the field (Mahlein et al., 2012). However, it should be noted that reliable detection of plant disease symptoms must be possible at a time that allows efficient plant protection measures (Le Cointe et al., 2016; Reynolds et al., 2012). If this is not the case, site-specific forecasting approaches offer another possibility to estimate the spatial occurrence of the disease under consideration. This can be based on information on disease occurrence from previous years or on factors that, depending on the disease, can influence its development and spread (e.g. soil conditions, topography, stand visibility; Bjerre et al., 2006). Based on these spatial information, it is possible to model the risk of infestation, i.e. the probability of an infestation of the respective plant disease in specific areas of a field (Ortiz et al., 2011). In order to be able to make statements on the actual occurrence of the disease to prepare site-specific applications, supplementary field observations in the specific subareas are necessary (Bjerre et al., 2006).

Environmental effects of site-specific pesticide applications were not investigated in the context of this study. However, the potential of site-specific pesticide applications for environmental protection is discussed in the literature (JRC, 2014, Larson et al., 1997). Sitespecific applications of pesticides were successful in reducing groundwater contamination (JRC, 2014). However, since the positive effects of precision agriculture technology are not directly perceivable by farmers, the technology will diffuse slowly, even if financial support is available. This phenomenon has been observed in the United States of America and in Europe (Takács-György et al., 2014).

Ecological effects of site-specific fungicide applications have not been investigated so far in the published literature. However, experts estimate that reduced use of fungicides could lead to decreased exposure to honey bees (Lückmann et al., 2020). A declining amount of residues in nectar and pollen of forage plants is another potentially positive environmental effect in honey bees (Lückmann et al., 2020). According to Bremmer et al. (2021), precision agriculture has a potentially positive impact on increasing biodiversity and pollinators and reducing climate change effects without reducing yields or farmers income.

Moreover, for the direct injection spraying system presented here, pesticides and water are mixed just before reaching the nozzle. This is an important environmental advantage, because there is no spray mixture left over as with conventional field sprayers. In addition, up to $80 \%$ less water is required for cleaning operations compared to conventional spraying systems.

Additionally, within the scope of documentation obligations, European farmers must prove compliance with environmental regulations. JRC (2014) already suggested that precision agriculture assistant systems could be extended with environmental auditing services. The data management within the automatic application assistant, as developed in the 'AssSys' project could prove to be an advantage for farmers due to transparency of documenting plant protection measures. This is especially relevant, if farmers are controlled by governmental authorities. Improvements in the legal framework can also expand access to precision farming and thereby its overall societal benefits (Finger et al., 2019).

\section{Investment costs of precision agriculture technology}

Based on the assumptions, the annual investment costs of the technology presented in the site-specific scenarios were $21 € \mathrm{ha}^{-1}$ to $37 € \mathrm{ha}^{-1}$, on average $17 € \mathrm{ha}^{-1}$ higher than those of the conventional scenario. With $111 € \mathrm{ha}^{-1}$ of herbicide cost savings and $43 € \mathrm{ha}^{-1}$ of 
fungicide cost savings, the savings for pesticides were higher than the investment costs. As mentioned above, compared to the savings in the site-specific pesticide applications, the costs of precision agriculture technology in the scenarios were not as considerable. The scenario with the greatest herbicide savings compared to the conventional applications, was the scenario with drone service and field sprayer upgrade (S2 c), where the investment costs were also the lowest. The scenario with the highest herbicide costs comprising the purchase of sensors and a new direct injection sprayer ( $\mathrm{S} 1 \mathrm{a}$ ), had the highest investment costs. The most important finding here is that, even when investment costs of precision agriculture technology were included, the extended gross margins are still $20 \%$ higher than in the conventional treatment. This finding highlights the economic advantage of site-specific applications.

Gerhards et al. (2004) calculated annual investment costs for monitoring with precision agriculture technology of $7 € \mathrm{ha}^{-1}$ for online methods with camera and $11 € \mathrm{ha}^{-1}$ for offline methods with camera. A three-chamber sprayer with $21 \mathrm{~m}$ working width for site-specific application of pesticides amounted to $14 € \mathrm{ha}^{-1}$ (Gerhards et al., 2004). This results in total costs of $21 € \mathrm{ha}^{-1}$ for online methods and $25 € \mathrm{ha}^{-1}$ for offline methods (Gerhards et al. (2004). In the study presented, the calculated annual investment costs for online methods were similar with 31 to $37 € \mathrm{ha}^{-1}$ for site-specific application of pesticides per ha and for offline methods between 21 and $34 €$ ha $^{-1}$, including the costs for application technology with two-chamber sprayer with $27 \mathrm{~m}$ working width.

Profitability, satisfaction and success are reasons for farmers to invest in precision agriculture technologies (Kilian, 2004; Paustian \& Theuvsen, 2017). As Kilian (2004) suggested, direct subsidies motivate farmers to change to site-specific application techniques. Further data are needed on the perceived benefits with using automated site-specific systems at farm level (Lowenberg-DeBoer et al., 2020). Moreover, pesticide reduction by farmers depends on their risk attitude and they may need successful examples of how to decrease pesticide use without economic losses (Bakker et al., 2021). Confidence towards the new technologies and the perception of usefulness of them positively influenced the intention to adjust to precision agriculture technologies (Adrian et al., 2005; Paustian \& Theuvsen, 2017).

\section{Minimum application area (Break-Even-Point)}

The field areas of the study presented ranged between plot sizes from 2 to 7 ha, meaning that even higher savings might be possible with larger field plots in agricultural practice. Barroso et al. (2003) found that site-specific treatments were only profitable if more than one third of the field was not treated with herbicides. Similar to Barroso et al. (2003), the field trials presented here show that the untreated field area ranged between 0 and $73 \%$, on average $25 \%$. This means that in most cases more than one third of the field was not treated with herbicides. In the scenario analysis, the untreated field area ranged between 20 and $30 \%$, on average $27 \%$.

The necessary minimum area of site-specific applications with precision agriculture technologies depends on the amount of reduced herbicides or the share of field area not treated and potential additional labour costs by (not yet automatic) monitoring procedures, and of course, the investment costs of the precision agriculture technology (Lettner et al., 2001). The results of the scenario analysis presented here, show minimum application areas between 314 and 3024 ha. Calculations by Lettner et al. (2001) resulted in minimum 
application areas between 26 and 334 ha. Model estimations from Takăcs-György (2007) resulted in 205 ha of minimum application area. Pedersen et al. (2020) concluded that it is even likely that farms with an area above 100 to 150 ha will gain a net financial benefit from using precision agriculture technologies. The results indicate that the higher the savings in herbicides and the lower the additional labour costs, the smaller will be the minimum application area for a profitable use of precision agriculture technology. With hopefully lower investment costs in the near future, minimum application areas might be also profitable for medium and small farms in Germany. Regarding (additional) labour costs of monitoring, experiences from German demonstration farms show that intensive monitoring helps to optimise plant protection measures (Helbig et al., 2016; Roßberg et al., 2018). If the time-consuming monitoring procedures are supported with sensors and drones soon, the respective labour costs of monitoring will also decrease rapidly, representing another economic advantage of precision agriculture technology.

\section{Conclusions}

The aim of this paper was to show the economic potential of site-specific herbicide and fungicide application scenarios with direct injection and automatic application assistant in northern Germany. The investment costs included the purchase or services of drones and sensors for detection of weeds and fungal diseases to prepare site-specific treatments. Average cost savings of $66 \%$ resulted from the scenario analysis when sitespecific and conventional monitoring and applications were compared. Extended gross margins of site-specific monitoring and application scenarios were on average $20 \%$ above the conventional applications. The results revealed that it is possible to compensate investment costs by pesticide cost savings. Estimations for a minimum site-specific application area with at least $30 \%$ pesticide cost savings to compensate investment costs of direct injection, automatic application assistant as well as weed and fungal disease detection with sensor or drone resulted in at least 300 ha per year.

However, the results of the scenario analysis show that site-specific pesticide applications in winter wheat, spring wheat and winter barley might help to reduce the use of pesticides compared to conventional treatments. The extent of pesticide cost savings depends on many factors, including field heterogeneity, crop rotation and production intensity. More studies are needed on similar technologies to show their economic advantages and to convince farmers of using them in agricultural practice.

Finally, site-specific pesticide applications with application assistant systems and direct injection may help farmers to meet the goals of the European Green Deal. The precision agriculture technology presented will be ready for agricultural practice soon. Further targeted subsidies will be necessary to support farmers in their investments and the implementation of this new technology in their agricultural practice.

Supplementary Information The online version contains supplementary material available at https://doi. org/10.1007/s11119-022-09888-1.

Acknowledgements We want to thank our engaged project partners for the excellent cooperation. Weed monitoring, generation of application maps and site-specific herbicide applications were performed by $\mathrm{C}$. Wellhausen and J.-P. Pohl. Monitoring of fungal pathogens in the field trials was conducted by M. Herrmann. The authors gratefully acknowledge the financial support by the German Federal Ministry of Food and Agriculture and the Federal Office for Agriculture and Food. 
Author contributions All authors contributed to the study conception and design. Material preparation, data collection and analysis were performed by SR, IK, J-PP and MH. The first draft of the manuscript was written by SR and all authors commented on previous versions of the manuscript. All authors read and approved the final manuscript.

Funding Open Access funding enabled and organized by Projekt DEAL. The authors gratefully acknowledge the financial support by the German Federal Ministry of Food and Agriculture and the Federal Office for Agriculture and Food with the funding code 313-06.01-28-1-49.079-15.

Data availability The authors declare that all data and materials support their published claims and comply with field standards.

Code availability Not applicable.

\section{Declarations}

Conflict of interest The authors declare that they have no conflict of interests.

Open Access This article is licensed under a Creative Commons Attribution 4.0 International License, which permits use, sharing, adaptation, distribution and reproduction in any medium or format, as long as you give appropriate credit to the original author(s) and the source, provide a link to the Creative Commons licence, and indicate if changes were made. The images or other third party material in this article are included in the article's Creative Commons licence, unless indicated otherwise in a credit line to the material. If material is not included in the article's Creative Commons licence and your intended use is not permitted by statutory regulation or exceeds the permitted use, you will need to obtain permission directly from the copyright holder. To view a copy of this licence, visit http://creativecommons.org/licenses/by/4.0/.

\section{References}

Adrian, A. M., Norwood, S. H., \& Mask, P. L. (2005). Producers' perceptions and attitudes toward precision agriculture technologies. Computers and Electronics in Agriculture, 48(3), 256-271.

Agra-Europe. (2020). Acht von zehn Bauern setzen bereits digitale Techniken ein (Eight out of ten farmers already use digital techniques). Länderberichte, 19, 15-16.

Agravis Raiffeisen, AG (2019). Pflanzenschutz- und Schädlingsbekämpfungsmittel (plant protection and pest control products). Preisliste, Hannover, p. 74.

Agravis Raiffeisen, AG (2020). Pflanzenschutz- und Schädlingsbekämpfungsmittel (plant protection and pest control products). Preisliste, Hannover, p. 200.

Agricon. (2020). Precision farming with Agricon. Best use of machines, operating resources and work time. Retrieved January 20, 2022, from www.agricon.de.

Agricultural Market Information Company. (2019). Marktbilanz Getreide, Ölsaaten und Futtermittel. (Compilation of market prices of cereals, oilseeds and fodder) (p. 223).

Agricultural Market Information Company. (2020). Marktbilanz Getreide, Ölsaaten und Futtermittel. (Compilation of market prices of cereals, oilseeds and fodder) (p. 219).

Ancev, T., Whelan, B., \& McBratney, A. (2004). On the economics of precision agriculture: Technical, informational and environmental aspects. In Paper presented at the annual meeting of Australian Agricultural and Resource Economics Society, p. 25.

Bakker, L., Sok, J., van der Werf, W., \& Bianchi, F. J. J. A. (2021). Kicking the habit: What makes and breaks farmers' intentions to reduce pesticide use? Ecological Economics, 180, 106868.

Barroso, J., Fernandez-Quintanilla, C., Maxwell, B., \& Rew, L. (2003). Using site-specific weed management for control of wild oats in Spain: An economic evaluation. Precision Agriculture, 4, 47-52.

Barzman, M., Bàrberi, P., Nicholas, A., Birch, E., Boonekamp, P., Dachbrodt-Saaydeh, S., et al. (2015). Eight principles of integrated pest management. Agronomy for Sustainable Development, 35 , 1199-1215.

Biological Federal Institute. (1996). Richtlinie für die Prüfung von Fungiziden gegen Pseudocercosporella herpotrichoides (Fron) Deighton (Halmbruchkrankheit) an Getreide (guideline for testing fungicides against Pseudocercosporella herpotrichoides (Fron) Deighton (eyespot) on cereals). Berlin: Biological Federal Institute for Agriculture and Forestry 
Bjerre, K. D., Jørgensen, L. N., \& Olesen, J. E. (2006). Site-specific management of crop diseases. Handbook of precision agriculture-principles and applications (pp. 207-251). The Hayworth Press.

Bongiovanni, R., \& Lowenberg-Deboer, J. (2004). Precision agriculture and sustainability. Precision Agriculture, 5, 359-387.

Bremmer, J., Riemens, M., \& Reinders, M. (2021). The future of crop protection in Europe. Study for the Panel for the Future of Science and Technology (p. 34). European Parliamentary Research Service, Brussels, Belgium, 34 pp.

Christensen, S., Sogaard, H. T., Kudsk, P., Norremark, M., Lund, I., Nadimi, E. S., et al. (2009). Sitespecific weed control technologies. Weed Research, 49, 233-241.

Dammer, K.-H., \& Ehlert, D. (2006). Variable-rate fungicide spraying in cereals using a plant cover sensor. Precision Agriculture, 7(2), 137-148. https://doi.org/10.1007/s11119-006-9005-X

Dammer, K.-H., Thöle, H., Volk, T., \& Hau, B. (2009). Variable-rate fungicide spraying in real time by combining a plant cover sensor and a decision support system. Precision Agriculture, 10(5), 431-442. https://doi.org/10.1007/s11119-008-9088-7

Federal Ministry of Food and Agriculture. (2013). National action plan on sustainable use of plant protection products. Retrieved January 23, 2022, from http://nap-pflanzenschutz.de/fileadmin/SITE_ MASTER/content/Startseite/Englisch/NAP_2013_En.pdf.

Federal Ministry of Food and Agriculture. (2019). Ernte 2018. Mengen und Preise (Harvest 2018: Volumes and prices). Berlin, Germany, p. 38.

Federal Ministry of Food and Agriculture. (2020). Ernte 2019. Mengen und Preise (Harvest 2019: Volumes and prices). Berlin, Germany, p. 39.

Federle, C., Scheiber, M., Kleinhenz, B., Röhrig, M., Feldhaus, J., Golla, B., et al. (2014). Pesticide application manager (PAM) - decision support in crop protection based on terrain-, machine-, business- and public data. In Proceedings international conference of agricultural engineering, (pp. 1-8). European Society of Agricultural Engineers.

Finger, R., Swinton, S., El Benni, N., \& Walter, A. (2019). Precision farming at the nexus of agricultural production and the environment. Annual Review of Resource Economics, 11, 313-335.

Fortuna, G., \& Michalopoulos, S. (2020). MEP: Precision farming should be part of member states' recovery plans. Retrieved January 20, 2022, from www.euractiv.com/section/agriculture-food/ news/mep-precision-farming-should-be-part-of-member-states-recovery-plans.

Gerhards, R., \& Christensen, S. (2003). Real-time weed detection, decision making and patch spraying in maize, sugar beet, winter wheat and winter barley. Weed Research, 43(6), 385-392.

Gerhards, R., Dicke, D., \& Oebel, H. (2004). Precision farming in weed control. In P. Zwerger \& T. Eggers (Eds.), Weed science on the go (pp. 55-65). University of Hohenheim.

Gerhards, R., Gutjahr, C., Weis, M., Keller, M., Sökefeld, M., Möhring, J., et al. (2011). Using precision farming technology to quantify yield effects attributed to weed competition and herbicide application. Weed Research, 52, 6-15.

Hamouz, P., Hamouzová, K., Holec, J., \& Tyšer, L. (2013). Impact of site-specific weed management on herbicide savings and winter wheat yield. Plant, Soil and Environment, 59, 101-107.

Hamouz, P., Hamouzová, K., Holec, J., \& Tyšer, L. (2014). Impact of site-specific weed management in winter crops on weed populations. Plant, Soil and Environment, 60, 518-524.

Helbig, J., Gummert, A., Kahl, A., \& Goltermann, S. (2016). Projekt „Demonstrationsbetriebe integrierter Pflanzenschutz" (project „,demonstration farms integrated plant protection“). Getreidemagazin, 6, 18-21.

Herrmann, M., Federle, C., Röhrig, M., \& Kleinhenz, B. (2020). Teilflächenspezifische Prognose von Halmbasiskrankheiten in Winterweizen - Aktueller Stand im Forschungsvorhaben AssSys (Key performance indicators and economic assessment of site-specific pesticide applications with direct injection and application assistance system). Journal of Cultivated Plants, 72(5), 189-190.

Hinck, S., Kloepfer, F., \& Schuchmann, G. (2016). Precision Farming-Bodeneigenschaften erfassen (Precision Agriculture-Capturing soil properties). Darmstadt, Germany: KTBL-Heft 111.

Hufnagel, J., Herbst, R., Jarfe, A. \& Werner, A. (2004). Precision Farming: Analyse, Planung, Umsetzung in die Praxis (Precision Agriculture: Analysis, planning, implementation in practice). KTBL-Loseblattsammlung.

Jambhulkar, P. P., \& Meshram, N. M. (2013). Site specific crop protection. In S. Banik (Ed.), Current concepts in crop protection (pp. 240-280). Lanham, India: Studium Press.

JRC (Joint Research Centre of the European Commission), Pablo, J., Zarco-Tejada, P. J., Hubbard, N. \& Loudjani, P. (2014). Precision agriculture: An opportunity for EU farmers-potential support with the cap 2014-2020. Retrieved from Brussels. 
Kilian, B. (2004). Ökonomie von Precision Farming. Precision Farming-Analyse, Planung und Umsetzung in die Praxis (economics of precision farming. Precision farming analysis, planning and implementation in practice). KTBL-Schrift 419.

KTBL. (2018/2019). KTBL-Feldarbeitsrechner (fieldwork calculator of the German advisory board for technology and construction in agriculture). Retrieved January 20, 2022, from https://www.ktbl.de/ webanwendungen/feldarbeitsrechner.

Korres, N. E., Burgos, N. E., Travos, I., Vurro, M., Gitsopoulos, T. K., Varanasi, V., et al. (2019). New directions for integrated weed management: Modern technologies, tools and knowledge discovery. Advances in Agronomy, 155, 243-319.

Larson, W. E., Lamb, J. A., Khakural, B. R., Ferguson, R. B., \& Rehm, G. W. (1997). Potential of sitespecific management for nonpoint environmental protection. In F. J. Pierce \& E. J. Sadler (Eds.), The state of site-specific management for agriculture (pp. 337-367). Wiley.

Le Cointe, R., Simon, T. E., Delarue, P., Herve, M., Leclerc, M., \& Poggi, S. (2016). Reducing the use of pesticides with site-specific application: The chemical control of Rhizoctonia solani as a case of study for the management of soil- borne diseases. PLOS ONE, 11(9), 18. https://doi.org/10.1371/journ al.pone.0163221

Lettner, J., Hank, K., \& Wagner, P. (2001). Ökonomische Potenziale der teilschlagspezifischen Unkrautbekämpfung (economic potential of site-specific weed control). Berichte Über Landwirtschaft, 79, $107-139$.

Lowenberg-DeBoer, J., Huang, I. Y., Grigoriadis, V., \& Blackmore, S. (2020). Economics of robots and automation in field crop production. Precision Agriculture, 21, 278-299.

Lückmann, J., Kaiser, S., \& von Blanckenhagen, F. (2020). Precision farming-consideration of reduced exposure in the pollinator risk assessment. In Poster presented at the 14th international symposium of the ICP-PR Bee protection group - hazards of pesticides to bees (pp. 78-82), Julius Kühn-Institute.

Mahlein, A.-K., Oerke, E.-C., Steiner, U., \& Dehne, H.-W. (2012). Recent advances in sensing plant diseases for precision crop protection. European Journal of Plant Pathology, 133(1), 197-209. https://doi. org/10.1007/s10658-011-9878-Z

McBratney, A., Whelan, B., \& Ancev, T. (2005). Future directions of precision agriculture. Precision Agriculture, 6, 7-23.

Mußhoff, O., \& Hirschauer, H. (2016). Modernes Agrarmanagement. Betriebswirtschaftliche Analyse- und Planungsverfahren (Modern Agricultural Management. Business analysis and planning methods) (Vol. 4). Verlag Franz Vahlen.

Nordmeyer, H., Zuk, A., \& Häusler, A. (2003). Experiences of site-specific weed control in winter cereals. Precision Agriculture, 4, 457-462.

Oebel, H., \& Gerhards, R. (2005). Site-specific weed control using digital image analysis and georeferenced application maps, On-farm experiences. In J. V. Stafford (Ed.), Proceedings of the 5th European conference on precision agriculture (pp. 131-138). Academic Publishers.

Ortiz, B. V., Sullivan, D. G., Perry, C., \& Vellidis, G. (2011). Delineation of management zones for southern root-knot nematode using fuzzy clustering of terrain and edaphic field characteristics. Communications in Soil Science and Plant Analysis, 42(16), 1972-1994. https://doi.org/10.1080/00103624.2011. 591471

Paustian, M., \& Theuvsen, L. (2017). Adoption of precision agriculture technologies by German crop farmers. Precision Agriculture, 18(5), 701-716. https://doi.org/10.1007/s11119-016-9482-5

Pedersen, S. M., Pedersen, M. F., Ørum, J. E., Fountas, S., Balafoutis, A. T., van Evert, F. K., et al. (2020). Economic, environmental and social impacts. Agricultural internet of things and decision support for precision smart farming (pp. 279-330). Elsevier Inc. https://doi.org/10.1016/B978-0-12-818373-1. 00006-8

Pohl, J.-P., Rautmann, D., Nordmeyer, H., \& von Hörsten, D. (2017). Site-specific application of plant protection products in Precision Farming by direct injection. In J. A. Taylor, D. Cammarano, A. Prahsar, A. Hamilton (Eds.). In Proceedings of the 11th European conference of precision agriculture. Advances in animal biosciences, 8, 255-258.

Pohl, J.-P., Jahncke, D., Feise, D., von Hörsten, D., \& Wegener, J. K. (2021). Digital assistance system as a holistic solution for site-specific and resource-saving crop protection. Journal of Cultivated Plants, 73(5-6), 110-115.

Rajmis, S., Golla, B., Uhl, B., Martini, D., \& Kehlenbeck, H. (2016). Ökonomische Bewertung eines Entscheidungshilfesystems im Pflanzenschutz am Beispiel von Winterweizen (Economic assessment of a decision support system in crop protection using winter wheat as an example). Julius-Kühn-Archiv, 454, 551-552. 
Rasmussen, J., Azim, S., Nielsen, J., Feld Mikkelsen, B., Horfarter, R., \& Christensen, S. (2020). A new method to estimate the spatial correlation between planned and actual patch spraying of herbicides. Precision Agriculture, 21, 713-728.

Rentenbank (2021). Förderung des BMEL-Investitionsprogramm Landwirtschaft (funding from the BMEL-investment program agriculture). Retrieved January 21, 2022, from www.rentenbank.de/ dokumente/bundesprogramme/Positivliste-Investitionsprogramm-Landwirtschaft.pdf.

Reynolds, G. J., Windels, C. E., MacRae, I. V., \& Laguette, S. (2012). Remote sensing for assessing Rhizoctonia crown and Root Rot Severity in Sugar Beet. Plant Disease, 96, 497-505. https://doi.org/10.1094/ PDIS-11-10-0831

Rohleder, B., Krüsken, B., \& Reinhardt, H. (2020). Digitalisierung in der Landwirtschaft 2020 (Digitisation in agriculture 2020). Retrieved January 21, 2022, from www.bitkom.org/Bitkom/Publikationen/Digit alisierung-in-der-Landwirtschaft-2020.

Roßberg, D., Dachbrodt-Saaydeh, S., Helbig, J., Paap, M., \& Kehlenbeck, H. (2018). NEPTUN, PAPA, Vergleichs- und Demonstrationsbetriebe oder Wer hat da noch den Durchblick? (NEPTUN, PAPA, comparison and demonstration farms or who still has a clue?). Gesunde Pflanzen. https://doi.org/10.1007/ s10343-018-0421-4(lastaccessed22/12/20)

Röder, N., Ackermann, A., Baum, S., \& Rudolph, S. (2018). Status quo und aktuelle Entwicklung der landwirtschaftlichen Nutzflächen in Deutschland (Status quo and current developments in agricultural land use in Germany). Natur und Landschaft, 93, 250-257.

Schneider, M., \& Wagner, P. (2008). Economic evaluation of precision farming in a farm wide context. In A. Werner, F. Dreger, J. Schwarz (Eds.), Information-guided crop production with precision farming as a central substantive and technical prerequisite for sustainable development of agricultural land use (pp. 401-436). Leibniz Centre for Agricultural Landscape Research (ZALF) e.V.

Schroers, J. O., Gerhards, R., \& Kunisch, M., et al. (2010). Economic evaluation of precision crop protection measures. In E. C. Oerke (Ed.), Precision crop protection-the challenge and use of heterogeneity (pp. 417-426). Springer.

Swinton, M. S. (2005). Economics of site-specific weed management. Weed Science, 53(2), 259-263.

Takăcs-György, K. (2007). Economic aspects of chemical reduction on farming-future role of precision farming. Acta Scientiarum Polonorum, 5(2), 114-122.

Takăcs-György, K., \& Takăcs, I. (2009). Economic analysis of precision weed management. Cereal Research Communications, 37(4), 585-593.

Takács-György, K., Turek Rahoveanu, M. M., \& Takács, I. (2014). Sustainable new agricultural technology-economic aspects of precision crop protection. Procedia Economics and Finance, 8, 729-736. https://doi.org/10.1016/s2212-5671(14)00151-8

Timmermann, C., Gerhards, R., \& Kühbauch, W. (2003). The economic impact of site-specific weed control. Precision Agriculture, 4, 249-260.

Tona, E., Calcante, A., \& Oberti, R. (2018). The profitability of precision spraying on specialty crops: A technical-economic analysis of protection equipment at increasing technological levels. Precision Agriculture, 19(4), 606-629. https://doi.org/10.1007/s11119-017-9543-4

Wellhausen, C., Pflanz, M., Pohl, J.-P. \& Nordmeyer, H. (2020). Generierung von Unkrautverteilungskarten auf der Basis automatischer Annotierungen in Feldaufnahmen (generation of weed distribution maps based on automatic annotations in field surveys). Julius-Kühn-Archiv, Nr. 464 (2020): Tagungsband 29. Deutsche Arbeitsbesprechung über Fragen der Unkrautbiologie und - bekämpfung, 3-5. März 2020, Braunschweig. Julius-Kühn-Archiv, 464, 222.

Whetton, R. L., Waine, T. W., \& Mouazen, A. M. (2018). Evaluating management zone maps for variable rate fungicide application and selective harvest. Computers and Electronics in Agriculture, 153, 202-212. https://doi.org/10.1016/j.compag.2018.08.004

Publisher's Note Springer Nature remains neutral with regard to jurisdictional claims in published maps and institutional affiliations. 


\section{Authors and Affiliations}

Sandra Rajmis ${ }^{1,2}$. Isabella Karpinski ${ }^{1}$ (D) . Jan-Philip Pohl ${ }^{3} \cdot$ Marco Herrmann $^{4}$. Hella Kehlenbeck ${ }^{1}$

1 Julius Kühn Institute, Institute for Strategies and Technology Assessment, Stahnsdorfer Damm 81, 14532 Kleinmachnow, Germany

2 Center for Technology and Society, TU Berlin, Kaiserin-Augusta-Allee 104, 10553 Berlin, Germany

3 Julius Kühn Institute, Institute for Application Techniques in Plant Protection, Messeweg 11-12, 38104 Braunschweig, Germany

4 Central Institute for Decision Support Systems in Crop Protection, Rüdesheimer Str. 60-68, 55545 Bad Kreuznach, Germany 